\title{
Mineral status, metabolism and performance of dairy heifers receiving a combined trace element bolus and out-wintered on perennial ryegrass, kale or fodder beet
}

by Atkins, N.E., Bleach, E.C.L., Mackenzie, A.M., Hargreaves, P.R. and Sinclair, L.A.

Copyright, Publisher and Additional Information: This is the author accepted manuscript. The final published version (version of record) is available online via Elsevier.

This version is made available under the CC-BY-ND-NC licence: https://creativecommons.org/licenses/by-nc-nd/4.0/legalcode

Please refer to any applicable terms of use of the publisher

DOI: https://doi.org/10.1016/j.livsci.2019.103865 
1 Mineral status, metabolism and performance of dairy heifers

2 receiving a combined trace element bolus and out-wintered on

3 perennial ryegrass, kale or fodder beet.

4 N.E. Atkins ${ }^{a}$, E.C.L. Bleacha, A.M. Mackenzie ${ }^{a}$, P.R. Hargreaves ${ }^{\text {, }}$, L.A. Sinclaira,

5

6 a Department of Animal Production, Welfare and Veterinary Sciences, Harper Adams

7 University, Newport, Shropshire, TF10 8NB, United Kingdom

$8{ }^{b}$ Scotland's Rural College, Dairy Research and Innovation Centre, Hestan House,

9 Dumfries, Dumfries and Galloway, DG1 4TA, United Kingdom

10

11 Norton Atkins $\quad$ nortonatkins@gmail.com

12 Emma Bleach $\quad$ ebleach@harper-adams.ac.uk

13 Sandy Mackenzie amackenzie@harper-adams.ac.uk

14 Paul Hargreaves paul.hargreaves@sruc.ac.uk

15 Liam Sinclair $\quad \underline{\text { lsinclair@harper-adams.ac.uk }}$

16

$17 *^{*}$ Corresponding author.

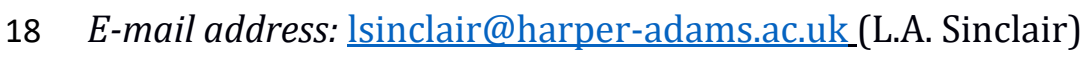


20 The effects of a cobalt (Co), copper (Cu), selenium (Se), and iodine (I) trace-

21 mineral ruminal bolus on the mineral status and performance of out-wintered,

22 pregnant dairy heifers was investigated. Nine commercial farms grazing pasture

$23(\mathrm{G})$, kale $(\mathrm{K})$, or fodder beet $(\mathrm{F})$ were used ( $\mathrm{n}=3$ per forage), with forty heifers on

24 each farm randomly allocated to not receive $(\mathrm{B}-)$ or receive $(\mathrm{B}+)$ two combined

25 mineral boluses. Mean plasma Co concentrations were 0.021 and $0.041 \mu \mathrm{mol} / \mathrm{L}$ in

26 B- and $\mathrm{B}+$ respectively $(p<0.001)$, with serum vitamin $\mathrm{B}_{12}$ also higher in heifers

27 receiving $\mathrm{B}+$ than $\mathrm{B}-(p<0.001)$. Mean plasma Se concentration was 0.50 and 0.82

$28 \mu \mathrm{mol} / \mathrm{L}$ in $\mathrm{B}$ - and $\mathrm{B}+$ respectively, with heifers that received $\mathrm{B}+$ also having a higher

$29(p<0.05)$ mean blood GSH-Px concentration $(30$ and $76 \mathrm{U} / \mathrm{mL}$ haematocrit in $\mathrm{B}-$

30 and $\mathrm{B}+$ respectively). Providing a mineral bolus did not affect plasma $\mathrm{Cu}$

31 concentration in heifers receiving $\mathrm{G}$ or $\mathrm{F}(p<0.05)$, but was higher in $\mathrm{KB}+$

32 compared to KB- $(p<0.05)$ at the middle and end of the out-wintering period.

33 Heifers receiving KB- also had a lower haemoglobin and red blood cell count, but

34 a higher mean corpuscular volume than $\mathrm{KB}+$ at the end of the out-wintering period.

35 Animals receiving B- had a higher plasma thyroxine concentration $(p<0.05)$.

36 Neither the bolus nor forage type affected body weight $(p>0.05)$, however

37 condition score was higher $(p<0.05)$ in $\mathrm{B}+$ at the end of the study. It is concluded

38 that the provision of a trace mineral bolus increased plasma concentrations of the

39 minerals supplied, with the greatest benefits in animals grazing kale, but these

40 increases were not translated into improved performance.

41

42 Keywords: brassica, dairy heifer, forages, wintering, minerals, vitamin $\mathrm{B}_{12}$ 


\section{Introduction}

44

57 trace-mineral nutrition challenges which may impact animal health and

58 productivity. For instance, kale has been reported to be deficient in copper $(\mathrm{Cu})$,

59 cobalt (Co) and iodine (I) (Grace et al., 2010). Brassicas' also contain 60 glucosinolates, which hydrolyse in the rumen to produce goitrogens, interfering

61 with I absorption and inhibiting thyroxine synthesis (Barry et al., 1981). Kale is

62 also high in sulphur (S), a Cu metabolism antagonist (Suttle, 2010), with much of 63 the $\mathrm{S}$ in kale contained in the anti-nutritional factor S-methylcysteine sulphoxide, 64 which causes damage to red blood cells and can lead to haemolytic anaemia (Barry, 65 2013). In addition, soil particles adhere to pasture during winter and may typically 66 contribute around $10 \%$ of dry matter intake (DMI), potentially inhibiting mineral 
67 and element availability (Suttle et al., 1975), an effect that may be greater with

68 fodder beet grazed in situ. Fodder beet is also low in trace minerals such as Co and

69 selenium (Se; Atkins et al., 2018), although there is comparatively little published

70 data regarding the trace-mineral content of this forage. In addition, cold conditions

71 can increase thyroid activity (Tucker et al., 2007), and out-wintered animals may

72 benefit from additional I.

73 Achieving adequate live weight gain in heifers is generally considered an

74 important factor affecting both current and lifetime performance (Hoffman, 1997;

75 Le Cozler et al., 2011; Roche et al., 2015). Sub-optimal trace-mineral nutrition

76 during the heifer rearing period can impact on subsequent productivity with, for

77 example, low dietary concentration of $\mathrm{Co}$ or $\mathrm{Cu}$ restricting average daily gain (ADG)

78 in growing cattle (Mills et al., 1976; Schwarz et al., 2000), and $\mathrm{Cu}, \mathrm{Co}$, I and Se

79 supply are all important for immunity and fertility (Corah, 1996; Panousis et al.,

80 2001; Stabel et al., 1993). Recent surveys have indicated that in housed, winter-

81 fed dairy cows, minerals are generally supplied well in excess of requirements

82 (Sinclair and Atkins, 2015). In contrast, grazed animals present less control over

83 mineral nutrition (McDowell, 1996). Offering free-choice mineral licks can result

84 in in variable mineral intake between animals (Valk and Kogut, 1998), whilst

85 administering a reticulorumen trace-mineral bolus offers the opportunity to

86 deliver a consistent dose of selected trace-minerals throughout the grazing period

87 (Kendall et al., 2001). Despite mineral bolus use being common commercial

88 practice on many UK dairy farms (Sinclair and Atkins, 2015), the benefits of trace-

89 mineral supplementation on the mineral status, metabolism and performance in

90 lower-input, out-wintered heifer rearing systems are unclear. The aim of the 
91 current study was to investigate the effects of a trace-mineral bolus on blood

92 mineral status and performance in replacement heifers out-wintered on pasture,

93 kale or fodder beet, in commercial, spring-calving pasture based dairy farms.

94

\section{2. Material and methods}

96

97

98

99

100

101

102

103

104

105

106

107 months of age from February 2013, and were destined for a grazed grass

108 production system. A sub-set of 40 primiparous heifers were randomly selected

109 on each study farm, resulting in a total of 360 heifers recruited onto the study.

110 Within each farm, the 40 heifers were paired according to body weight (BW) and

111 body condition score (BCS; Mulvany, 1977) and randomly allocated to one of two

112 treatments; un-supplemented (B-) or supplemented with trace-mineral boluses

$113(\mathrm{~B}+)$. The $\mathrm{B}+$ heifers received two reticulorumen trace-mineral boluses (CoSeICure,

114 Telsol Ltd, Leeds, UK) according to the manufacturer's recommendations at the 
115 start of the study. Each bolus contained $\mathrm{Cu}(13.4 \mathrm{~g})$; Co (0.5 g); Se (0.15 g, as sodium

116 selenite) and I (1.0 g, as calcium iodate). No other mineral supplementation was

117 available during the study period. The heifers on each farm were kept together

118 throughout the winter and were managed within larger groups that included non-

119 trial heifers and received supplementary forage in the form of big bale perennial 120 ryegrass silage.

121

\subsection{Experimental routine and measurements}

The farms were visited on three occasions during the out-wintering period;

125 start (late October to early November 2012), middle (mid-December 2012), and

126 at the end of the out-wintering period (late January to early February 2013). The

127 initial visit coincided with the beginning of the out-wintering regime on each farm

128 ( \pm one week), and the final visit with the end of the out-wintering feeding regime,

129 prior to the onset of calving. On each visit, samples of pasture or forage crop and

130 supplementary forage were collected and stored at $-20^{\circ} \mathrm{C}$ prior to subsequent

131 analysis. Pasture samples were collected from 10 random positions in the

132 subsequent weeks grazing area at a height of approximately $4 \mathrm{~cm}$. Kale samples

133 were collected by cutting 10 random plants from the subsequent weeks grazing

134 area at approximately $5-10 \mathrm{~cm}$ above ground level, just above the woody base. The

135 plants were then chopped into approximately 3 to $5 \mathrm{~cm}$ pieces, mixed, quartered,

136 and mixed again to obtain a $1 \mathrm{~kg}$ sub-sample. Fodder beet samples were collected

137 by pulling 10 random plants from the subsequent weeks grazing area. The leaves

138 of each plant were separated from the bulb and the weight of leaf and bulb 
139 recorded. Leaves were then chopped and mixed, quartered and a sub sample 140 collected. Loose soil was washed from the bulb which was then cut into 141 approximately $2 \mathrm{~cm}$ cubes, mixed, quartered, and a $1 \mathrm{~kg}$ sub-sample obtained. 142 Samples of big bale silage were collected from the bales being fed on the day of the 143 visit. Crop and pasture yield, pre and post grazing, were assessed on each occasion 144 by quadrat cut $\left(10 \times 1 \mathrm{~m}^{2}\right.$ for $\mathrm{K}$ and $\mathrm{F}$, and $10 \times 0.1 \mathrm{~m}^{2}$ for $\left.\mathrm{G}\right)$, as described by Atkins 145 et al. (2018), and the area grazed, number of heifers, and silage fed to calculate the 146 proportion of crop and silage in the diet of each farm.

147 Beginning at approximately $1000 \mathrm{~h}$ on each visit body weight (BW) of the 148 heifers was recorded using electronic weigh-cells (Trutest, Auckland, New 149 Zealand), and body condition score (BCS) recorded. On visits 1 and 3, a hair length 150 sample was collected as described by Boyle et al. (2008). On each of the 3 visits 151 blood samples were collected from 12 pairs of study heifers via the coccygeal vein 152 into tubes (Becton Dickinson Vacutainer Systems, Plymouth, UK) containing $153 \mathrm{~K}_{2}$ EDTA, lithium heparin or without an anti-coagulant, and immediately stored on 154 ice until centrifuged at $1300 \mathrm{~g}$ and $4^{\circ} \mathrm{C}$ for 10 minutes. Plasma and serum were 155 decanted and stored at $-20^{\circ} \mathrm{C}$ until subsequent analysis. In addition, a sub-sample 156 of whole blood was stored at $-20^{\circ} \mathrm{C}$ prior to subsequent analysis. The farms 157 recorded calving date and calving-ease score as: 1 . No assistance/ calved unaided, 158 2. Farmer assistance - normal presentation, 3. Farmer assistance - mal 159 presentation, 4. Vet assistance.

160

\subsection{Chemical analysis}

162 
Forage samples were analysed for dry matter (DM) according to AOAC

164

165

166

167

168

169

170

171

172

173

174

(2012; 934.01) prior to milling through a $1 \mathrm{~mm}$ screen (Cyclone Mill, Retsch, Haan,

Germany). Dried, milled samples of fodder beet leaf and bulb were then bulked in proportion to the measured amount to create a representative sample of the whole crop. Crude protein (CP) concentration of the forages was determined by combustion using a LECO FP $528 \mathrm{~N}$ analyser (Leco Corporation, St. Joseph, MI) according to AOAC (2012; 990.03), neutral detergent fibre (NDF) content was determined according to Van Soest et al. (1991), and water-soluble carbohydrate (WSC) content as described by Thomas (1977). In addition, forage samples were digested using the DigiPREP digestion system (Qmx Laboratories, Essex, UK), for analysis by inductively coupled plasma mass spectrometry (ICP-MS; Thermo Fisher Scientific Inc., Hemel Hempstead, UK), as described by Sinclair and Atkins (2015). Briefly, 0.5 g duplicates of dried, milled sample were accurately weighed into a DigiTUBE and $1 \mathrm{~mL}$ of concentrated $\mathrm{HCl}$ and $6 \mathrm{~mL}$ of concentrated $\mathrm{HNO}_{3}$ added. The tubes were then heated over $30 \mathrm{~min}$ to $45^{\circ} \mathrm{C}$ in a DigiPREP heating block and held for $1 \mathrm{~min}$ before being increased over $25 \mathrm{~min}$ to $65^{\circ} \mathrm{C}$, held for another $5 \mathrm{~min}$, then increased over $15 \mathrm{~min}$ to $100{ }^{\circ} \mathrm{C}$ and refluxed for $40 \mathrm{~min}$. The digested samples were then diluted to $50 \mathrm{~mL}$ with purified water. On the same day as analysis, a reagent blank of $2 \% \mathrm{HNO}_{3}, 1 \%$ methanol and $0.1 \%$ Triton $\mathrm{X}$ (SigmaAldrich Ltd., Gillingham, UK) was prepared using purified water, with Gallium (Ga) as an internal standard. Calibration standards were prepared within an expected range of the analytes for content of calcium (Ca), magnesium (Mg), phosphorous (P), potassium, sodium (Na), S , Co , Se, $\mathrm{Cu}$, iron (Fe), zinc $(\mathrm{Zn})$, manganese $(\mathrm{Mn})$, and molybdenum (Mo). A $2.5 \mathrm{~mL}$ aliquot of digested sample was diluted with 2.5 
207 blood reference sample (Woodley Haematology Control, WD1154), with inter208 assay CV\% of $2.4,3.7,2.8,4.1,8.7,0.6,2.9$ and 3.2 for WBC, RBC, Hb, Hct, Plt, MCV, $209 \mathrm{MCH}$ and MCHC respectively. Sub-samples of whole blood samples were analysed 210 for glutathione peroxidase (GSH-Px; intra-assay CV\% 1.2) and superoxide 
211 dismutase (SOD; intra-assay CV\% 2.3) (Randox Laboratories, County Antrim, UK;

212 kit catalogue no. RS505 and SD125, respectively), using a Cobas Miras Plus auto 213 analyser (ABX Diagnostics, Bedfordshire, UK). Samples of blood serum were 214 analysed for $\beta$-hydroxybutyrate (3-OHB) and urea (Randox Laboratories, County 215 Antrim, UK; kit catalogue no. RB1008 and UR221; intra-assay CV\% 3.5 and 2.8 216 respectively). Blood serum from the initial and final visit were also analysed for 217 vitamin $\mathrm{B}_{12}(\mathrm{LOD}=33 \mathrm{pmol} / \mathrm{L}$, and $\mathrm{CV}$ for low, med and high quality controls were $21813.1,9.3$ and 7.9\% respectively) and thyroxine ( $\mathrm{T}_{4}$; LOD $=3.9 \mathrm{nmol} / \mathrm{L}$, and CV for 219 low, med and high quality controls were 8.7, 6.0 and 5.8\% respectively) using the

220

221 222 223 224 225 226 227 228 229 230 231

234 with the Wald statistic used to assess significance. 


\section{Results}

\subsection{Feed analysis and blood mineral concentration}

239

240 The DM content of the three grazed forages was similar (Table 2), with a mean 241 value of $151 \mathrm{~g} / \mathrm{kg} \mathrm{DM}$. Crude protein content tended to be lowest $(p<0.1)$ in the 242 fodder beet and highest in the kale. In contrast, water soluble carbohydrate was 243 highest $(p<0.05)$ in the fodder beet and lowest in the grass, with kale being 244 intermediate, whereas NDF concentration was lowest $(p<0.05)$ in the fodder beet 245 and highest in the grass. The chemical composition of the supplementary forage 246 was similar $(p>0.05)$ between farms, although on one farm that fed fodder beet 247 the forage DM content was high. The proportion of silage in the total diet was 0.81 248 in $\mathrm{G}, 0.25$ in $\mathrm{K}$ and 0.50 in $\mathrm{F}$ (s.e.d. $0.102, p=0.004$ ), and subsequently the diet of $249 \mathrm{G}$ were highest $(p<0.05)$ in NDF and lowest $(p<0.05)$ in WSC, whilst NDF was 250 lowest $(p<0.05)$ in the diet of K and WSC highest $(p<0.05)$ in the diet of F.

251 Calcium concentration was highest in kale, and lowest in fodder beet, with 252 an intermediate concentration in grass $(p<0.05)$, whereas $\mathrm{P}$ and potassium 253 concentration were similar $(p>0.05)$ across all forages (Table 2). The 254 concentration of $\mathrm{Na}$ and $\mathrm{Mg}$ were higher $(p<0.05)$ in fodder beet compared with 255 grass or kale. In contrast, kale had a higher $(p<0.05)$ concentration of $S$ than either 256 grass or fodder beet. Grass had a higher concentration $(p<0.05)$ of both Mn and 257 Co compared to kale or fodder beet, while $\mathrm{Fe}$ and $\mathrm{Cu}$ concentrations were lower ( $p$ $258<0.05)$ in kale than either grazed grass or fodder beet. The concentration of $\mathrm{Zn}$ 
259 also tended $(p<0.1)$ to be lowest in kale, while Se tended $(p<0.1)$ to be highest in 260 grass compared to the other 2 forages. Fodder beet had a lower concentration $(p$ $261<0.05$ ) of Mo compared to grass or kale. The mineral content of the supplementary 262 forage was similar across farms $(p>0.05)$. Total diet mineral intake differed 263 between forage source $(p<0.05)$ for $\mathrm{Ca}$, being highest in $\mathrm{K}$ and lowest in $\mathrm{F}$; Co, 264 where $\mathrm{G}$ was highest and $\mathrm{K}$ lowest; $\mathrm{Cu}$, where $\mathrm{K}$ was lower than $\mathrm{G}$ or F; Fe, where 265 G was highest and K lowest; and Mo, where G and K were higher than F.

266 Supplementation with mineral boluses increased plasma concentrations of 267 Co, Se and $\mathrm{Cu}(p<0.05$; Table 3). Mean plasma Co was 0.021 and $0.041 \mu \mathrm{mol} / \mathrm{L}$ in 268 B- and B+ respectively, with the concentration being higher at the middle and end 269 of the out-wintering period in $\mathrm{B}+$ compared to the beginning $(p<0.05)$. Mean 270 plasma Se concentration was 0.50 and $0.82 \mu \mathrm{mol} / \mathrm{L}$ in B- and B+ respectively, with 271 heifers that received a trace mineral bolus having higher concentrations at the 272 middle and end of out-wintering compared to the beginning $(p<0.05)$. In heifers 273 receiving GB-, plasma Se concentration was higher at the end of the out-wintering 274 period compared to animals receiving FB- $(p<0.05)$, but similar to those receiving 275 KB-. Mean plasma $\mathrm{Cu}$ concentration was 11.3 and $14.5 \mu \mathrm{mol} / \mathrm{L}$ in B- and B+ 276 respectively, and the provision of a mineral bolus did not affect plasma 277 concentrations in heifers receiving $\mathrm{G}$ or $\mathrm{F}(p>0.05)$, but in heifers receiving $\mathrm{K}$, 278 plasma $\mathrm{Cu}$ was higher $(p<0.05)$ in animals receiving a bolus $(\mathrm{KB}+)$ at the middle 279 and end of the out-wintering period compared to those that did not receive a bolus 280 (KB-). There was no effect of providing a mineral bolus on plasma $\mathrm{Mn}, \mathrm{Fe}, \mathrm{Zn}$ or Mo 281 concentration ( $p<0.05$ ), which averaged 0.06, 62.312 .6 and $0.48 \mu \mathrm{mol} / \mathrm{L}$ 282 respectively. Plasma Fe concentration was lower $(p<0.05)$ at the end of the out- 
283 wintering compared to the beginning in heifers receiving $\mathrm{G}$ or $\mathrm{F}$, while in heifers

284 receiving $\mathrm{K}$, plasma $\mathrm{Zn}$ was lower $(p<0.05)$ at the middle compared to the

285 beginning. Plasma Zn concentration was also lower $(p<0.05)$ in heifers receiving

$286 \mathrm{G}$ at the middle of the out-wintering period, while in heifers fed $\mathrm{F}, \mathrm{Zn}$ was lower $(p$

$287<0.05)$ at the end. In heifers receiving G, plasma Mo concentration was higher $(p$

$288<0.05)$ at the middle and end of the out-wintering period compared to the

289 beginning. However, in heifers receiving $\mathrm{K}$, plasma Mo was lower $(p<0.05)$ at the

290 end of out-wintering compared to the beginning, while plasma Mo was similar ( $p>$

291 0.05) over the out-wintering period in heifers receiving F.

293

294

296

297

298

299

300

301

302 mineral boluses $(\mathrm{KB}+)$, had a higher $(p<0.05)$ serum vitamin $\mathrm{B}_{12}$ concentration at

303 the end of out-wintering compared to KB-. Heifers that received the trace-mineral

304 boluses had a higher $(p<0.001)$ mean blood SOD concentration than un-

305 supplemented heifers at the end of the out-wintering period, with mean

306 concentrations of 2067 and 2338 U/g Hb for B- and B+ respectively. However, 
there was no main effect $(p>0.05)$ of forage source, although heifers fed KB- had the lowest $(p<0.05)$ SOD at the end of the out-wintering period compared to any

309 of the other treatments. Heifers that received the boluses also had a higher $(p<$ 310 0.05) mean blood GSH-Px concentration than un-supplemented animals, with a 311 mean concentration at the end of out-wintering of 30 and $76 \mathrm{U} / \mathrm{mL}$ Hct in B- and $312 \mathrm{~B}+$ respectively. In heifers that received the trace mineral boluses, blood GSH-Px 313 concentration increased $(p<0.05)$ by the end of the out-wintering period 314 irrespective of forage source, but in animals that did not receive a mineral bolus 315 and grazed kale (KB-), blood GSH-Px concentration decreased $(p<0.05)$. The 316 serum concentration of $\mathrm{T}_{4}$ did not differ between treatments at the beginning of 317 the study $(p>0.05)$, with heifers that received $\mathrm{B}+$ having a similar $(p<0.05)$ 318 concentration at the end of the out-wintering period compared to the beginning, 319 while those that received B- had a higher $(p<0.05)$ concentration. Provision of the 320 mineral boluses did not affect serum 3-OHB concentration $(p>0.05)$, with an 321 overall mean of $0.38 \mathrm{mmol} / \mathrm{L}$ in $\mathrm{B}-$ and $\mathrm{B}+$. However, heifers receiving $\mathrm{K}$ had a 322 higher concentration of $3-\mathrm{OHB}$ at the end of out-wintering compared to the 323 beginning $(p<0.05)$, whereas in animals receiving $\mathrm{F}$, serum 3-OHB concentration 324 decreased with time $(p<0.05)$. Serum urea concentration was not affected by 325 providing mineral boluses $(p>0.05)$, with an overall mean of $4.1 \mathrm{mmol} / \mathrm{L}$ for B326 and $\mathrm{B}+$. In contrast, for heifers receiving any of the forages, serum urea 327 concentration was lower at the end of out-wintering period than the beginning $(p$ $328<0.05)$. 

overall mean count of 8.27 and $8.57 \times 10^{3}$ cells $/ \mathrm{mm}^{3}$ in $\mathrm{B}-$ and $\mathrm{B}+$ respectively, 334 although there was a trend $(p<0.1)$ for fewer WBC at the end compared to the 335 beginning of the out-wintering period in heifers receiving $\mathrm{F}$ along with a bolus 336 (FB+; Table 5). Similarly, the provision of the trace mineral boluses had no effect $337(p>0.05)$ on $\mathrm{Hb}$, with an overall mean concentration of $12.2 \mathrm{~g} / \mathrm{dL}$ blood. However, 338 there was an interaction between time and forage, with $\mathrm{Hb}$ being lower $(p<0.05)$ 339 during the middle and end compared to the beginning of the out-wintering period 340 in heifers receiving G or F. In contrast, in heifers fed $\mathrm{K}, \mathrm{Hb}$ was higher $(p<0.05)$ in 341 the middle compared to the beginning of the out-wintering period. The mineral 342 boluses had no effect $(p>0.05)$ on RBC, with a mean count of 7.73 and $7.79 \times 103$ 343 cells $/ \mathrm{mm}^{3}$ in $\mathrm{B}$ - and $\mathrm{B}+$, respectively. However, in heifers receiving $\mathrm{G}$ or $\mathrm{F}, \mathrm{RBC}$ was 344 lower $(p<0.05)$ during the middle and end compared to the beginning of the out345 wintering period. In contrast, at the end of out-wintering, heifers receiving $\mathrm{KB}+$ 346 had a higher $(p<0.05)$ RBC concentration than those receiving KB-. The mineral 347 boluses had no effect ( $p>0.05)$ on blood Hct volume, with an overall mean of 33.4 348 and $33.3 \%$ for B- and B+ respectively, but there was an effect of time, with Hct 349 being lower $(p<0.05)$ during the middle and end compared to the beginning of 350 the out-wintering period in heifers receiving G or F. In contrast, Hct increased $(p<$ 3510.05 ) in heifers receiving $\mathrm{K}$ between the beginning and middle of the out-wintering 352 period. Heifers that received the trace mineral boluses had a lower $(p<0.05)$ mean 353 MCV than those that did not, with an overall mean at the end of the out-wintering 354 period of 44.8 and $43.3 \mu \mathrm{m}^{3}$ in $\mathrm{B}$ - and $\mathrm{B}+$ respectively. The provision of the trace 
355 mineral boluses resulted in a higher $(p<0.05)$ MCV in heifers receiving KB+ than

356 KB-. In heifers receiving G, F or KB+, MCV did not change $(p>0.05)$ over the out-

357 wintering period. In contrast, in heifers receiving G or F, MCH decreased $(p<0.05)$

358 between the start and the end of out-wintering. The provision of the trace mineral

359 boluses had no effect $(p>0.05)$ on MCHC, with an overall mean of $36.8 \mathrm{~g} / \mathrm{dL}$.

360 However, in heifers receiving F, MCHC was lower $(p<0.05)$ at the end of out-

361 wintering compared to the beginning. In contrast, MCHC was higher $(p<0.05)$ at

362 the middle compared to the beginning of out-wintering in heifers fed $\mathrm{K}$, but was

363 unchanged $(p>0.05)$ in heifers fed G. There was no effect of the mineral bolus on

364 Plt count $(p>0.05)$, with an overall mean of $314 \times 103 / \mathrm{mm}^{3}$.

\subsection{Animal performance}

Provision of the trace mineral boluses did not affect $(p>0.05) \mathrm{BW}$, with an overall mean of $415 \mathrm{~kg}$ over the out-wintering period (Table 6). In heifers receiving

G, BW did not change between the start and middle of the out-wintering period,

371 but increased $(p<0.05)$ between the middle and the end. In contrast, the BW of 372 heifers receiving $\mathrm{F}$ increased $(p<0.05)$ between the start and middle, but was

373 similar $(p>0.05)$ between the middle and the end of out-wintering. The BW of 374 heifers receiving K increased $(p>0.05)$ at each measurement point during the out375 wintering period. Provision of the trace mineral boluses did not affect $(p>0.05)$ 376 ADG over the out-wintering period, with an overall mean of $245 \mathrm{~g} / \mathrm{d}$ between the 377 start and end of out-wintering.

378 Overall, the provision of the mineral boluses did not affect $(p>0.05)$ heifer 
379 BCS, with a mean of 2.57. However, at the end of the out-wintering period, heifers 380 that had received trace mineral boluses had a mean BCS that was 0.03 points 381 higher $(p<0.05)$ than those that did not. Overall, heifers lost BCS over the out382 wintering period $(p<0.05)$, with those receiving $\mathrm{G}$ or $\mathrm{K}$ losing $\mathrm{BCS}$ at each 383 measurement point, whilst those receiving F lost BCS between the middle and end 384 of out-wintering.

385 Coat length increased by $4.3 \mathrm{~mm}$ over the study period $(p<0.001)$, but 386 bolus provision had no effect ( $p>0.05)$, with a mean of 23.2 and $23.4 \mathrm{~mm}$ for B387 and $\mathrm{B}+$ respectively. There was no effect $(p>0.05)$ of forage source on the 388 proportion of heifers that calved unassisted, with a mean value of 0.89 , whilst the 389 provision of trace mineral boluses also had no effect ( $p=0.877$ ) on the proportion 390 of heifers that calved un-aided, with 0.11 and 0.10 (odds ratio $=0.95,0.47-1.91$ $39195 \% \mathrm{CI} ; n$ obs. = $166 \mathrm{~B}-, 165 \mathrm{~B}+$ ) requiring some assistance to calve in B- and $\mathrm{B}+$, 392 respectively.

\section{4. Discussion}

\subsection{Blood parameters}

In the current study the primary objective was to determine the effect of a 399 combined trace mineral bolus on the mineral status and performance of 400 replacement dairy heifers on commercial farms and out-wintered on pasture, 401 fodder beet and kale. These forages were used as they are the main out-wintering 402 forages used in temperate countries such as the UK, New Zealand and Ireland 
403 (Atkins et al., 2014; Edwards et al., 2017; Keogh et al., 2009). A combined trace

404 mineral bolus was used as some trace minerals (e.g. I) are not available in this form,

405 and combined boluses represent commercial practice on many farms (Sinclair and

406 Atkins, 2015). The provision of trace-mineral boluses in the current study had no

407 effect on plasma $\mathrm{Cu}$ concentration in animals fed $\mathrm{G}$ or $\mathrm{F}$, but concentrations were

408 increased in heifers fed kale. Blood Cu typically ranges between $11-25.6 \mu \mathrm{mol} / \mathrm{L}$

409 (mean $18 \mu \mathrm{mol} / \mathrm{L}$; Rushton, 1981), and plasma Cu of animals fed $\mathrm{K}$ without bolus

410 was $10.3 \mu \mathrm{mol} / \mathrm{L}$ by the end of the out-wintering period indicating marginal status.

411 The typical recommend dietary concentration of $\mathrm{Cu}$ is between $11-15 \mathrm{mg} / \mathrm{kg} \mathrm{DM}$

412 (NRC, 2001), and therefore the dietary $\mathrm{Cu}$ concentration (predicted from the

413 forage and supplementary feed) in the G, K and F treatments in the current study

414 were considerably lower at $4.2,2.1$ and $4.6 \mathrm{mg} \mathrm{Cu} / \mathrm{kg} \mathrm{DM}$, respectively.

415 Additionally, the high S content in kale was likely to have had an antagonistic effect

416 on $\mathrm{Cu}$ absorption due to the formation of thiomolybdates in the rumen (Suttle,

417 2010). Using the prediction equations of Suttle and McLauchlin (1976) and the

418 mean forage S and Mo concentrations resulted in a predicted absorption co-

419 efficient of $\mathrm{Cu}(\%)$ of 4.5 and 4.4 in the grass and fodder beet fed animals

420 respectively, but only $2.5 \%$ in the kale fed animals, further compounding the low

421 dietary concentration in animals grazing this forage. However, $\mathrm{Cu}$ deficiency is not

422 immediately reflected in plasma $\mathrm{Cu}$, as hepatic $\mathrm{Cu}$ is metabolised to maintain

423 homeostasis (Evans, 1973), and plasma Cu has been shown to be a poor indicator

424 of hepatic reserves (Sinclair et al., 2013, 2017). The reduced SOD levels in kale fed

425 heifers that did not receive a mineral bolus may also indicate that these animals

426 were deficient in $\mathrm{Cu}$, although all values were low compared to other studies that 
427 have fed additional S and Mo to dairy cattle (Sinclair et al., 2013, 2017). Animals

428 fed kale have previously been reported to demonstrate symptoms of $\mathrm{Cu}$ deficiency

429 and haemolytic anaemia due to ruminal production of SMCO (Barry et al., 1981).

430 In the current study, heifers fed kale without a bolus had a lower $\mathrm{Hb}$ and RBC, but

431 a greater MCV at the end of out-wintering than those fed kale with a bolus. These

432 effects suggest the onset of anaemia in heifers fed kale, as elevated MCV is

433 indicative of a bone marrow response and the presence of immature red blood

434 cells (Otter, 2013). This negative effect of kale was, however, mitigated by the

435 trace-mineral bolus, and $\mathrm{Cu}$ supplementation of animals fed kale has previously

436 been reported to allow the recovery from haemolytic anaemia (Barry et al., 1981).

437 Provision of trace-mineral boluses increased the concentration of Co in the

438 plasma of heifers. The NRC (2001) stated the requirement for Co as $0.11 \mathrm{mg} / \mathrm{kg}$

$439 \mathrm{DM}$, while others have estimated it as low as $0.06 \mathrm{mg} / \mathrm{kg} \mathrm{DM}$ in grazing cattle

440 (Clark et al., 1999). More recent studies in high yielding dairy cows has

441 demonstrated that a dietary supply of $0.21 \mathrm{mg} / \mathrm{kg} \mathrm{DM}$ is more than sufficient to

442 meet the demands during the peri-parturient period and that there was no benefit

443 to additional Co or vitamin $\mathrm{B}_{12}$ (administered per os or injection) on performance

444 or indicators of ketosis (Weerathilake et al., 2018). The Co content of grazed grass

445 in this study was approximately 10 times above requirements and consequently

446 additional Co would not have been expected to have any benefit. In contrast, the

447 Co content of kale in this study was $0.05 \mathrm{mg} / \mathrm{kg} \mathrm{DM}$, approximately half the

448 required dietary level (NRC, 2001). Within the rumen, elemental cobalt (Co) is

449 used by bacteria to synthesise vitamin $B_{12}$ and animal status is generally assessed

450 by measuring blood vitamin $\mathrm{B}_{12}$ concentration. Vitamin $\mathrm{B}_{12}$ has two principal 
451 metabolic functions in cattle; firstly, methlycobalamin acts as a co-factor in the

452 transformation of methylmalonyl CoA to succinyl CoA which is then used within

453 the liver for the synthesis of glucose from propionate (McDowell, 2000). Secondly,

454 adenosylcobalamin is a co-factor in methionine synthase which is involved in the

455 synthesis of methionine from homocysteine (McDowell, 2000). A threshold

456 concentration of $150 \mathrm{pmol}$ vitamin $\mathrm{B}_{12} / \mathrm{L}$ has been suggested, above which there

457 is little benefit to animal performance (Duplessis et al., 2017), although others

458 have set the threshold at $90 \mathrm{pmol} / \mathrm{L}$ (Grace et al., 2014). In the current study, all

459 serum $\mathrm{B}_{12}$ concentrations were intermediate between these two threshold values.

460 The low Co content of the kale may explain the decrease in vitamin B12 status in

461 un-supplemented heifers fed this forage over the out-wintering period compared

462 to the increase in supplemented animals. Despite fodder beet fed animals

463 receiving an adequate dietary concentration of $\mathrm{Co}$, the vitamin $\mathrm{B}_{12}$ status of heifers

464 decreased over the out-wintering period, regardless of receiving a bolus. This

465 reduction in vitamin $\mathrm{B}_{12}$ status may have been as consequence of the low fibre and

466 high water soluble content of fodder beet, as ruminal vitamin B12 synthesis has

467 been reported to be decreased in animals fed low roughage diets, most probably

468 due to a low ruminal pH decreasing microbial synthesis (Smith et al., 1970; Walker

469 and Elliot, 1972).

470 Plasma Se concentrations in the current study increased in heifers that

471 received a trace mineral bolus across all the three forages, however, marginal

472 limits for serum Se are $0.10-0.12 \mu \mathrm{mol} / \mathrm{L}$ (Suttle, 2010), and all treatments

473 exceeded this threshold. Corresponding to plasma Se, plasma GSH-Px was

474 increased in heifers receiving the bolus. A recommended Se content in the diet of 
475 cattle is $0.05 \mathrm{mg} / \mathrm{kg} \mathrm{DM}$ in grazing situations where there is an adequate vitamin 476 E supply (CSIRO, 2007). All the forages offered to the out-wintered heifers in this 477 study were well in excess of this level of Se. However, even in the pasture, which 478 had the highest concentration of Se at $0.23 \mathrm{mg} / \mathrm{kg} \mathrm{DM}$, levels were below the 0.3 $479 \mathrm{mg} / \mathrm{kg}$ DM recommended by NRC (2001). Plasma GSH-Px concentration in heifers 480 receiving pasture or fodder beet without a trace mineral bolus did not alter over 481 the out-wintered period, further suggesting that Se concentration was adequate in 482 the basal diet. However, there was a reduction from 46 to $18 \mathrm{U}$ GSH-Px/mL Hct in 483 heifers receiving kale without a bolus, despite kale containing a similar level of Se 484 to the fodder beet $(0.12 \mathrm{mg} / \mathrm{kg} \mathrm{DM})$. High dietary $\mathrm{S}$ may antagonise Se metabolism 485 (Arthington, 2008), and plasma Se levels have been observed to decrease linearly 486 with increasing dietary S concentration in dairy cows (Ivancic and Weiss, 2001). 487 The $\mathrm{S}$ content in kale is known to be high and a mean concentration of $5.8 \mathrm{~g} / \mathrm{kg} \mathrm{DM}$ 488 was recorded on the farms in the current study. However, increasing dietary S from 4892.0 to $7.8 \mathrm{~g} / \mathrm{kg}$ DM was previously observed to have little effect on GSH-Px 490 concentration in cattle (Khan et al., 1987). Selenium deficiency has not previously 491 been considered important with brassica diets, however the free amino acid s492 methyl cysteine sulphoxide (SMCO) present in kale has been implicated in reduced 493 GSH-Px activity of cattle and sheep (Barry et al., 1981). Barry et al. (1981) also 494 suggested that $\mathrm{Cu}$ and Se status are related, as $\mathrm{Cu}$ containing SOD forms a coupling 495 with Se containing GSH-Px in the erythrocytes, with SOD catalysing the reduction 496 of superoxide anions to hydrogen peroxide and GSH-Px reducing hydrogen 497 peroxide to water. As with GSH-Px, blood levels of SOD were also lower in the 498 heifers fed kale without a bolus in this study. 
500 to increase in Se deficient animals (Arthur et al., 1993; Wichtel et al., 1996). Both

501 kale and fodder beet fed heifers in the current study had similar dietary Se 502 concentrations and also had higher concentrations of $\mathrm{T}_{4}$ in the animals that did not 503 receive a trace mineral bolus, despite a greater than required $(0.33 \mathrm{mg} / \mathrm{kg} \mathrm{DM}$; 504 NRC, 2001) I content in all three forages. This could indicate that thyroid function 505 could have been restricted by the dietary Se content in kale and fodder beet fed 506 heifers without a bolus and further work may be warranted to determine the effect 507 of Se in animals fed these forages. It is also well established that brassica crops 508 such as kale contain high levels of cyanogenic goitrogens which can be overcome 509 by additional dietary $\mathrm{I}$, which is reflected in serum $\mathrm{T}_{4}$ concentrations, with values 510 of $25-50 \mathrm{nmol} / \mathrm{L}$ indicating marginal status (Suttle, 2010). In the current study 511 serum $\mathrm{T}_{4}$ concentrations exceeded this threshold on all treatments, and were little 512 affected by the provision of a bolus. In contrast, thiouracil-type goitrogens are not 513 influenced by dietary I supply, but are generally not present in sufficiently high 514 concentrations in brassicas such as kale, or in grass and fodder beet (Suttle, 2010).

516 4.2. Animal performance

The trace-mineral bolus appeared to have little effect on the physical 519 performance of pregnant, growing heifers over the out-wintering period in the 520 current study, although animals on all treatments were below the target weight at 521 calving for similar systems (Roche et al., 2015). Heifers that received the trace522 mineral boluses lost less body condition by the end of the study, however the effect 
523 was biologically small and may have little impact on production or fertility (Roche 524 et al., 2015). Heifers fed F, and to a lesser extent G, tended to receive a lower dietary 525 crude protein concentration, which may have been a limiting factor, but was not 526 reflected in their performance or plasma urea concentrations. Inadequate energy

527 intake may also have been limiting animal performance as the ADG of heifers in 528 this study was low, and below that reported for other commercial herds (Atkins et 529 al., 2013). Out-wintering systems have previously been reported to be able to 530 support high levels of performance with an ADG of $1.10 \mathrm{~kg} / \mathrm{d}$ in pregnant Holstein531 Friesian heifers fed a diet consisting of $70 \%$ kale and $30 \%$ grass silage (Kennedy 532 et al., 2012), and 1.24 or $0.95 \mathrm{~kg} / \mathrm{d}$ in pregnant Holstein heifers receiving fodder 533 beet or grazed grass with grass silage respectively (Atkins et al., 2018). Judson and 534 Edwards (2008) reported that many farmers feeding kale to pregnant dairy cows 535 in New Zealand and using a similar system to that described here, underestimated 536 the crops herbage mass or overestimated the cows' intake. The difference in 537 performance reported by previous studies involving out-wintered heifers and 538 those in this study could therefore be in part due to low or inaccurate feed 539 allocation.

\section{5. Conclusion}

544 containing trace-mineral boluses on animal performance, except body condition 545 prior to calving which was slightly higher in heifers receiving boluses. Provision of 
546 trace-mineral boluses increased plasma concentrations of the minerals supplied 547 except for $\mathrm{Cu}$ in heifers fed grass or fodder beet. Despite the increase in plasma Co 548 with heifers fed fodder beet, serum vitamin $B_{12}$ decreased in heifers fed this forage. 549 The blood metabolite and haematology results suggest that the trace-mineral 550 bolus was effective at counteracting many of the anti-nutritional factors associated 551 with kale. The use of a trace-mineral bolus when out-wintering pregnant heifers is

552 therefore recommended, particularly for heifers grazing kale, but further research 553 is required to more accurately define mineral requirements amongst the different 554 forages.

\section{Acknowledgements}

557

558 The authors would like to acknowledge the farmers' involved for facilitating this 559 study, the Agricultural and Horticultural Development Board for funding this study, 560 and for the technical assistance of S. Wilson and D. Ferguson.

\section{Conflict of interest statement}

564 The authors declare that there is no conflict of interest regarding the publication 565 of this article.

566

\section{References}


AOAC, 2012. Official Methods of Analysis of the Association of Official Analytical Chemistry, 19th ed. AOAC International, Washington, USA.

Arthington, J.D., 2008. Effects of supplement type and selenium source on measures of growth and selenium status in yearling beef steers. J. Anim. Sci. $86,1472-1477$.

Arthur, J.R., Nicol, F., Beckett, G.J., 1993. Selenium deficiency, thyroid hormone metabolism, and thyroid hormone deiodinases. Am. J. Clin. Nutr. 57, 236S239S.

Atkins, N.E., Bleach, E.C.L., Sinclair, L.A., 2018. Periparturient and early lactation performance and metabolism of replacement Holstein-Friesian heifers outwintered on fodder beet or perennial ryegrass compared with winter housing. Grass Forage Sci. 73, 828-840.

Atkins, N.E., Walley, K., Bleach, E.C.L., Sinclair, L.A., 2014. A survey of current practice among dairy farmers out-wintering replacement heifers in Great Britain. Adv. Anim. Biosci. 5, 218.

Barry, T.N., 2013. The feeding value of forage brassica plants for grazing ruminant livestock. Anim. Feed Sci. Technol. 181, 15-25.

Barry, T.N., Reid, T.C., Millar, K.R., Sadler, W.A., 1981. Nutritional evaluation of kale (Brassica oleracea) diets:2. Copper deficiency, thyroid function, and selenium status in young cattle and sheep fed kale for prolonged periods. J. Agric. Sci. 96, 269-282.

Bates, D., Mächler, M., Bolker, B., Walker, S., 2015. Fitting Linear Mixed-Effects Models Using \{lme4\}. J. Stat. Softw. 67, 1-48.

Boulton, A.C., Rushton, J., Wathes, D.C., 2015. Culling in the dairy herd: have cows 
paid back their cost of rearing? Adv. Anim. Biosci. 6, 198.

Boulton, A.C., Rushton, J., Wathes, D.C., 2015. The Management and Associated Costs of Rearing Heifers on UK Dairy Farms from Weaning to Conception. Open J. Anim. Sci. 5, 294-308.

Boyle, L.A., Boyle, R.M., French, P., 2008. Welfare and performance of yearling dairy heifers out-wintered on a woodchip pad or housed indoors on two levels of nutrition. Animal 2, 769-778.

Clark, R.G., Ellison, R.S., Mortleman, L., Kirks, J.A., Henderson, H.V., 1999. Absence of a weight gain response to Vitamin B12 supplementation in weaned dairy heifers grazing pastures of marginal cobalt content. N. Z. Vet. J. 47, 125-127.

Commonwealth Scientific and Industrial Research Organisation (CSIRO), 2007. Nutrient Requirements of Domesticated Ruminants. CSIRO Publishing, Collingwood, Victoria, Australia.

Cope, C.M., Mackenzie, A.M., Wilde, D., Sinclair, L.A., 2009. Effects of level and form of dietary zinc on dairy cow performance and health. J. Dairy Sci. 92, 2128-2135.

Corah, L., 1996. Trace mineral requirements of grazing cattle. Anim. Feed Sci. Technol. 59, 61-70.

Duplessis, M., Lapierre, H., Pellerin, D., Laforest, J.-P., Girard, C.L., 2017. Effects of intramuscular injections of folic acid, vitamin B12, or both, on lactational performance and energy status of multiparous dairy cows. J. Dairy Sci. 100, 4051-4064.

Edwards, J.P., Mashlan, K., Dalley, D.E., Pinxterhuis, J.B., 2017. A survey of dairy cow wintering practices in Canterbury, New Zealand. Anim. Prod. Sci. 57, 
Evans, G.W., 1973. Copper homeostasis in the mammalian system. Physiol. Rev.

619

620

621

622

623

624

625

626

627

628

629

630

631

632

633

634

635

636

637

638

639

640 Kennedy, E., Coughlan, F., Murphy, J.P., Fitzgerald, S., 2012. The effect of winter 
diet on pre-partum wieght gain and post-partum milk production of grazing primiparous animals, in: Grassland Science in Europe, Vol. 17. pp. 243-245.

Keogh, B., French, P., McGrath, T., Storey, T., Mulligan, F.J., 2009. Effect of three forages and two forage allowances offered to pregnant dry dairy cows in winter on periparturient performance and milk yield in early lactation. Grass Forage Sci. 64, 292-303.

Khan, A.A., Lovejoy, D., Sharma, A.K., Sharma, R.M., Prior, M.G., Lillie, L.E., 1987. Effects of high dietary sulphur on enzyme activities, selenium concentrations and body weights of cattle. Can. J. Vet. Res. 51, 174-80.

Le Cozler, Y., Gallard, Y., Dessauge, F., Peccatte, J.R., Trommenschlager, J.M., Delaby, L., 2011. Performance and longevity of dairy heifers born during winter 1 (W1) and reared according to three growth profiles during winter 2 (W2) in a strategy based on first calving at 36 months of age. Livest. Sci. 137, 244254.

McDowell, L.R., 2000. Vitamins in Animal and Human Nutrition, Second. ed. Iowa State University Press, Ames, Iowa, USA.

McDowell, L.R., 1996. Feeding minerals to cattle on pasture. Anim. Feed Sci. Technol. 60, 247-271.

Mills, C.F., Dalgarno, A.C., Wenham, G., 1976. Biochemical and pathological changes in tissues of Friesian cattle during the experimental induction of copper deficiency. Br. J. Nutr. 35, 309-331.

Mulvany, P., 1977. Dairy cow condition scoring. Paper No. 4468. National Institute for Research in Dairying. Reading, UK.

National Research Council (NRC), 2001. Nutrient Requirements of Dairy Cattle, 
Seventh Re. ed. National Academy Press, Washington D.C.

Otter, A., 2013. Diagnostic blood biochemistry and haematology in cattle. In Pract. 35, 7-16.

Panousis, N., Karatzias, H., Roubies, N., Papasteriadis, A., Frydas, S., 2001. Effect of selenium and vitamin $\mathrm{E}$ on antibody production by dairy cows vaccinated against Escherichia coli. Vet. Rec. 149, 643-646.

R Core Team, 2016. R: A Language and Environment for Statistical Computing.

Roche, J.R., Dennis, N.A., Macdonald, K.A., Phyn, C.V.C., Amer, P.R., White, R.R., Drackley, J.K., 2015. Growth targets and rearing strategies for replacement heifers in pasture-based systems: a review. Anim. Prod. Sci. 55, 902-915.

Rushton, B., 1981. Veterinary Laboratory Data. BVA Publications.

Schwarz, F.J., Kirchgessner, M., Stangl, G.I., 2000. Cobalt requirement of beef cattle - feed intake and growth at different levels of cobalt supply. J. Anim. Physiol. Anim. Nutr. (Berl). 83, 121-131.

Sinclair, L.A., Atkins, N.E., 2015. Intake of selected minerals on commercial dairy herds in central and northern England in comparison with requirements. J. Agric. Sci. 153, 743-752.

Sinclair, L.A., Hart, K.J., Johnson, D., Mackenzie, A.M., 2013. Effect of inorganic or organic copper fed without or with added sulfur and molybdenum on the performance, indicators of copper status, and hepatic mRNA in dairy cows. J. Dairy Sci. 96, 4355-4367.

Sinclair, L.A., Johnson, D., Wilson, S., Mackenzie, A.M., 2017. Added dietary sulfur and molybdenum has a greater influence on hepatic copper concentration, intake, and performance in Holstein-Friesian dairy cows offered a grass 
silage- rather than corn silage-based diet. J. Dairy Sci. 100, 4365-4376.

Smith, R.M., Marston, L.H.R., Gräsbeck, R., Ignatius, R., Järnefelt, J., Lindén, H., Mali, A., Nyberg, W., Hine, D.C., Dawbarn, M.C., McDougall, E.I., Marston, H.R., Allen, S.H., Smith, R.M., Norman, A.G., Jenkins, S.H., 1970. Production, absorption, distribution and excretion of vitamin B12 in sheep. Br. J. Nutr. 24, 857-877.

Stabel, J.R., Spears, J.W., Brown, T.T., 1993. Effect of copper deficiency on tissue, blood characteristics, and immune function of calves challenged with infectious bovine rhinotracheitis virus and Pasteurella hemolytica. J. Anim. Sci. 71, 1247-1255.

Suttle, N.F., Alloway, B.J., Thornton, I., 1975. An effect of soil ingestion on the utilization of dietary copper by sheep. J. Agric. Sci. 84, 249-254.

Suttle, N.F., McLauchlin, M., 1976. Predicting the effects of dietary molybdenum and sulphur on the availability of copper to ruminants., in: The Proceedings of the Nutrition Society. p. 22A-23A.

Suttle N F, 2010. Mineral Nutrition of Livestock, Forth. ed. CAB International, Wallingford, Oxfordshire, UK.

Thomas, T.A., 1977. An automated procedure for the determination of soluble carbohydrates in herbage. J. Agric. Sci. 28, 639-642.

Tucker, C.B., Rogers, A.R., Verkerk, G.A., Kendall, P.E., Webster, J.R., Matthews, L.R., 2007. Effects of shelter and body condition on the behaviour and physiology of dairy cattle in winter. Appl. Anim. Behav. Sci. 105, 1-13.

Valk, H., Kogut, J., 1998. Salt block consumption by high yielding dairy cows fed rations with different amounts of NaCl. Livest. Prod. Sci. 56, 35-42.

Van Soest, P.J., Robertson, J.B., Lewis, B.A., 1991. Methods for dietary fiber, neutral 
$714 \quad$ nutrition. J. Dairy Sci. 74, 3583-3597.

715 Walker, C.K., Elliot, J.M., 1972. Lactational Trends in Vitamin B12 Status on

716 Conventional and Restricted-Roughage Rations. J. Dairy Sci. 55, 474-479.

717 Weerathilake, W.A.D. V, Brassington, A.H., Williams, S.J., Kwong, W.Y., Sinclair, L.A., 718 Sinclair, K.D., 2018. Added dietary cobalt or vitamin B12, or injecting vitamin

719 B12 does not improve performance or indicators of ketosis in pre- and post-

720 partum Holstein-Friesian dairy cows. Animal in press.

$721 \quad$ https://doi.org/10.1017/S175173111800232X

722 Wichtel, J.J., Craigie, A.L., Freeman, D.A., Varela-Alvarez, H., Williamson, N.B., 723 1996. Effect of Selenium and Iodine Supplementation on Growth Rate and 724 on Thyroid and Somatotropic Function in Dairy Calves at Pasture. J. Dairy $725 \quad$ Sci. $79,1865-1872$.

726

727

728 
Table 1

Limit of detection (LOD), limit of quantification (LOQ), intra-assay CV\%, and certified reference material results of ICP-MS analysis

\begin{tabular}{|c|c|c|c|c|c|c|c|c|c|c|}
\hline \multirow[b]{3}{*}{ Element } & \multirow[b]{3}{*}{$\begin{array}{l}\text { LOD, } \\
\mu \mathrm{l} / \mathrm{l}\end{array}$} & \multirow[b]{3}{*}{$\begin{array}{l}\mathrm{LOQ} \\
\mu \mathrm{l} / \mathrm{l}\end{array}$} & \multirow{2}{*}{\multicolumn{2}{|c|}{ intra-assay CV\% }} & \multicolumn{6}{|c|}{ Certified reference material } \\
\hline & & & & & \multicolumn{3}{|c|}{ EU BCR-129, hay } & \multicolumn{3}{|c|}{ EU BCR-708, dairy concentrate } \\
\hline & & & Feed & Plasma & $\begin{array}{c}\text { Certified } \\
\text { level }\end{array}$ & $\begin{array}{c}\text { Analysed } \\
\text { level }\end{array}$ & $\begin{array}{c}\% \\
\text { recovered }\end{array}$ & $\begin{array}{l}\text { Certified } \\
\text { level }\end{array}$ & $\begin{array}{c}\text { Analysed } \\
\text { level }\end{array}$ & $\begin{array}{c}\% \\
\text { recovered }\end{array}$ \\
\hline \multicolumn{11}{|c|}{$\mathrm{g} / \mathrm{kg}$ DM } \\
\hline $\mathrm{Ca}$ & 55.9 & 186 & 1.0 & & $6.40 \pm 0.10$ & $6.10 \pm 0.41$ & 95 & $4.8 \pm 0.5$ & $4.5 \pm 0.3$ & 93 \\
\hline $\mathrm{Na}$ & 15.7 & 52.4 & 0.6 & & 3.49 & $3.77 \pm 0.04$ & 108 & & & \\
\hline Mg & 0.46 & 1.52 & 0.4 & & $1.45 \pm 0.04$ & $1.50 \pm 0.01$ & 104 & $1.47 \pm 0.22$ & $1.57 \pm 0.018$ & 107 \\
\hline$P$ & 4.75 & 15.8 & 0.7 & & $2.36 \pm 0.07$ & $2.37 \pm 0.03$ & 100 & $4.7 \pm 0.4$ & $4.7 \pm 0.1$ & 100 \\
\hline $\mathrm{K}$ & 1.53 & 5.10 & 0.4 & & $33.8 \pm 0.8$ & $36.1 \pm 0.5$ & 107 & & & \\
\hline $\mathrm{S}$ & 99.5 & 332 & 4.0 & & $3.16 \pm 0.04$ & $2.74 \pm 0.37$ & 87 & & & \\
\hline \multicolumn{11}{|c|}{$\mathrm{mg} / \mathrm{kg} \mathrm{DM}$} \\
\hline Co & 0.01 & 0.02 & 1.2 & 6.4 & 0.121 & $0.099 \pm 0.047$ & 81 & & & \\
\hline $\mathrm{Cu}$ & 0.04 & 0.12 & 1.2 & 2.3 & 10 & $9.7 \pm 0.1$ & 97 & $37 \pm 4$ & $42 \pm 1.4$ & 114 \\
\hline $\mathrm{Se}$ & 0.04 & 0.13 & 5.9 & 1.7 & 0.025 & $0.024 \pm 0.010$ & 97 & & & \\
\hline Zn & 0.09 & 0.32 & 1.1 & 1.7 & $32.1 \pm 1.7$ & $28.0 \pm 6.1$ & 87 & & & \\
\hline $\mathrm{Fe}$ & 1.90 & 6.34 & 0.6 & 1.2 & 114 & $102.9 \pm 5.9$ & 90 & & & \\
\hline $\mathrm{Mn}$ & 0.01 & 0.03 & 0.6 & 5.3 & 72 & $76.3 \pm 2.6$ & 106 & & & \\
\hline Mo & 0.01 & 0.02 & 0.7 & 2.5 & 1 & $1.0 \pm 0.1$ & 96 & & & \\
\hline
\end{tabular}


Table 2

Chemical composition of the grazed and supplementary forage and total diet fed to pregnant dairy heifers out-wintered between November 2012 and February 2013 on nine commercial spring-calving farms. Heifers grazed either pasture $(G)$, kale $(K)$ or fodder beet (F), supplemented with baled grass silage ( $\mathrm{n}=3$ )

\begin{tabular}{|c|c|c|c|c|c|c|c|c|c|c|c|c|c|c|c|}
\hline & \multicolumn{5}{|c|}{ Grazed forage } & \multicolumn{5}{|c|}{ Supplementary forage } & \multicolumn{5}{|c|}{ Total diet } \\
\hline & $\mathrm{G}$ & $\mathrm{K}$ & $\mathrm{F}$ & SED & $P$-value & $\mathrm{G}$ & K & $\mathrm{F}$ & SED & $P$-value & $\mathrm{G}$ & $\mathrm{K}$ & $\mathrm{F}$ & SED & $P$-value \\
\hline $\mathrm{DM}, \mathrm{g} / \mathrm{kg}$ & 161 & 134 & 158 & 12.9 & 0.151 & 388 & 368 & 541 & 150.7 & 0.495 & 343 & 192 & 324 & 68.2 & 0.131 \\
\hline CP, g/kg DM & 128 & 164 & 87 & 24.7 & 0.053 & 113 & 121 & 101 & 17.1 & 0.555 & 115 & 153 & 92 & 19.6 & 0.054 \\
\hline NDF, g/kg DM & 521 & 302 & 179 & 24.5 & $<0.001$ & 601 & 554 & 628 & 38.5 & 0.230 & 583 & 365 & 402 & 45.9 & 0.007 \\
\hline WSC, g/kg DM & 100 & 256 & 494 & 37.7 & $<0.001$ & 19 & 29 & 78 & 33.4 & 0.244 & 35 & 201 & 288 & 64.5 & 0.021 \\
\hline \multicolumn{16}{|c|}{ Macro-mineral, g/kg DM } \\
\hline $\mathrm{Ca}$ & 7.49 & 15.2 & 3.23 & 0.707 & $<0.001$ & 5.91 & 5.64 & 3.34 & 1.376 & 0.202 & 6.39 & 12.8 & 3.45 & 0.844 & $<0.001$ \\
\hline $\mathrm{Na}$ & 0.65 & 1.20 & 4.75 & 0.908 & 0.008 & 2.45 & 1.32 & 2.93 & 1.564 & 0.600 & 2.21 & 1.22 & 3.96 & 1.244 & 0.163 \\
\hline $\mathrm{Mg}$ & 1.55 & 1.64 & 2.55 & 0.295 & 0.027 & 1.80 & 1.95 & 1.99 & 0.481 & 0.923 & 1.79 & 1.72 & 2.31 & 0.384 & 0.316 \\
\hline$P$ & 2.77 & 3.26 & 2.06 & 0.492 & 0.123 & 2.79 & 2.91 & 2.94 & 0.529 & 0.954 & 2.77 & 3.18 & 2.52 & 0.489 & 0.439 \\
\hline $\mathrm{K}$ & 16.8 & 31.7 & 24.9 & 5.71 & 0.101 & 24.0 & 28.0 & 20.6 & 4.99 & 0.396 & 22.5 & 30.8 & 21.3 & 3.79 & 0.089 \\
\hline $\mathrm{S}$ & 1.90 & 5.84 & 0.49 & 1.182 & 0.010 & 2.23 & 2.25 & 3.24 & 1.823 & 0.823 & 2.19 & 4.93 & 1.97 & 1.487 & 0.166 \\
\hline \multicolumn{16}{|c|}{ Trace-mineral, mg/kg DM } \\
\hline Co & 1.05 & 0.05 & 0.28 & 0.20 & 0.007 & 0.29 & 0.14 & 0.11 & 0.088 & 0.166 & 0.43 & 0.08 & 0.19 & 0.068 & 0.006 \\
\hline $\mathrm{Cu}$ & 7.74 & 1.64 & 4.86 & 0.95 & 0.002 & 3.52 & 3.64 & 3.97 & 1.076 & 0.911 & 4.20 & 2.14 & 4.61 & 0.743 & 0.033 \\
\hline $\mathrm{Se}$ & 0.23 & 0.12 & 0.12 & 0.048 & 0.084 & 0.24 & 0.14 & 0.12 & 0.131 & 0.656 & 0.21 & 0.12 & 0.12 & 0.099 & 0.577 \\
\hline I & 1.92 & 0.62 & 2.53 & 1.863 & 0.604 & 0.44 & 0.40 & 0.88 & 0.488 & 0.577 & 0.80 & 0.52 & 1.39 & 0.903 & 0.639 \\
\hline $\mathrm{Zn}$ & 38.3 & 15.4 & 37.0 & 9.13 & 0.080 & 28.2 & 20.2 & 22.6 & 7.07 & 0.549 & 29.6 & 16.6 & 30.2 & 7.10 & 0.176 \\
\hline $\mathrm{Fe}$ & 1709 & 127 & 1168 & 310.4 & 0.010 & 805 & 351 & 359 & 333.5 & 0.361 & 1276 & 183 & 770 & 198.4 & 0.004 \\
\hline $\mathrm{Mn}$ & 213 & 15 & 57 & 20.3 & $<0.001$ & 209 & 87 & 260 & 98.1 & 0.270 & 217 & 33 & 160 & 75.3 & 0.117 \\
\hline Mo & 1.29 & 0.97 & 0.13 & 0.201 & 0.003 & 1.06 & 1.31 & 0.74 & 0.307 & 0.256 & 1.11 & 1.06 & 0.41 & 0.240 & 0.049 \\
\hline
\end{tabular}


Table 3 Plasma trace-mineral concentration at the beginning, middle and end of a three month out-wintering period, in pregnant crossbred dairy heifers out-wintered on either grazed pasture (G), kale (K) or fodder beet (F), without (B-) or with (B+) a trace-mineral bolus

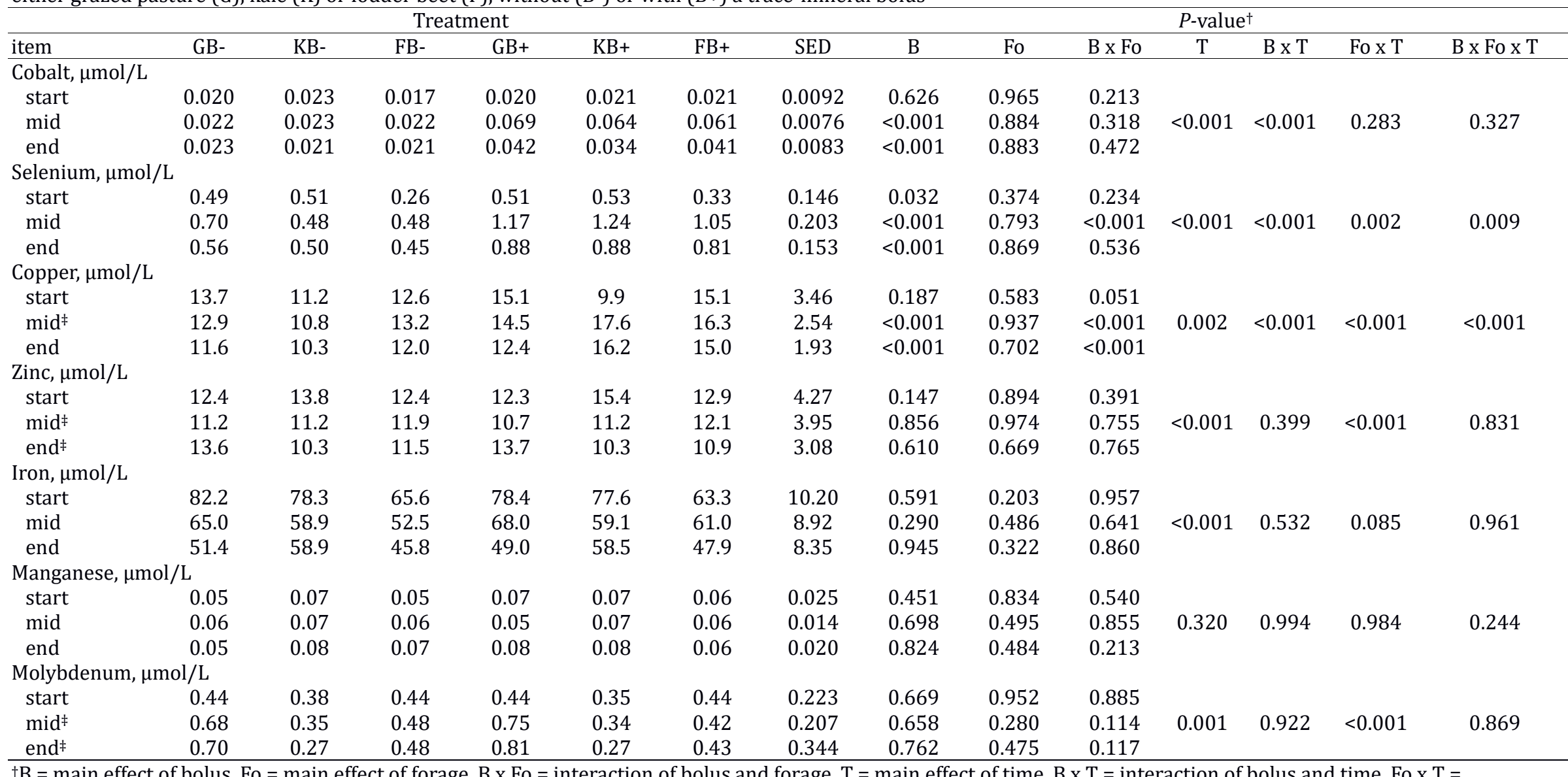

${ }^{\dagger} \mathrm{B}=$ main effect of bolus, Fo = main effect of forage, $\mathrm{B} \times \mathrm{Fo}=$ interaction of bolus and forage, $\mathrm{T}=$ main effect of time, $\mathrm{B} \times \mathrm{T}=$ interaction of bolus and time, Fo $\mathrm{x} \mathrm{T}=$ interaction of forage and time, $\mathrm{B} \times \mathrm{Fo} \times \mathrm{T}=$ interaction of bolus, forage and time

$\neq$ means adjusted for initial value covariate 


\section{Table 4}

Blood vitamin, enzyme and metabolite concentrations at the beginning and end of a three month out-wintering period, in pregnant crossbred dairy heifers out-wintered on either grazed pasture $(\mathrm{G})$, kale $(\mathrm{K})$ or fodder beet $(\mathrm{F})$, without $(\mathrm{B}-)$ or with $(\mathrm{B}+)$ a trace-mineral bolus

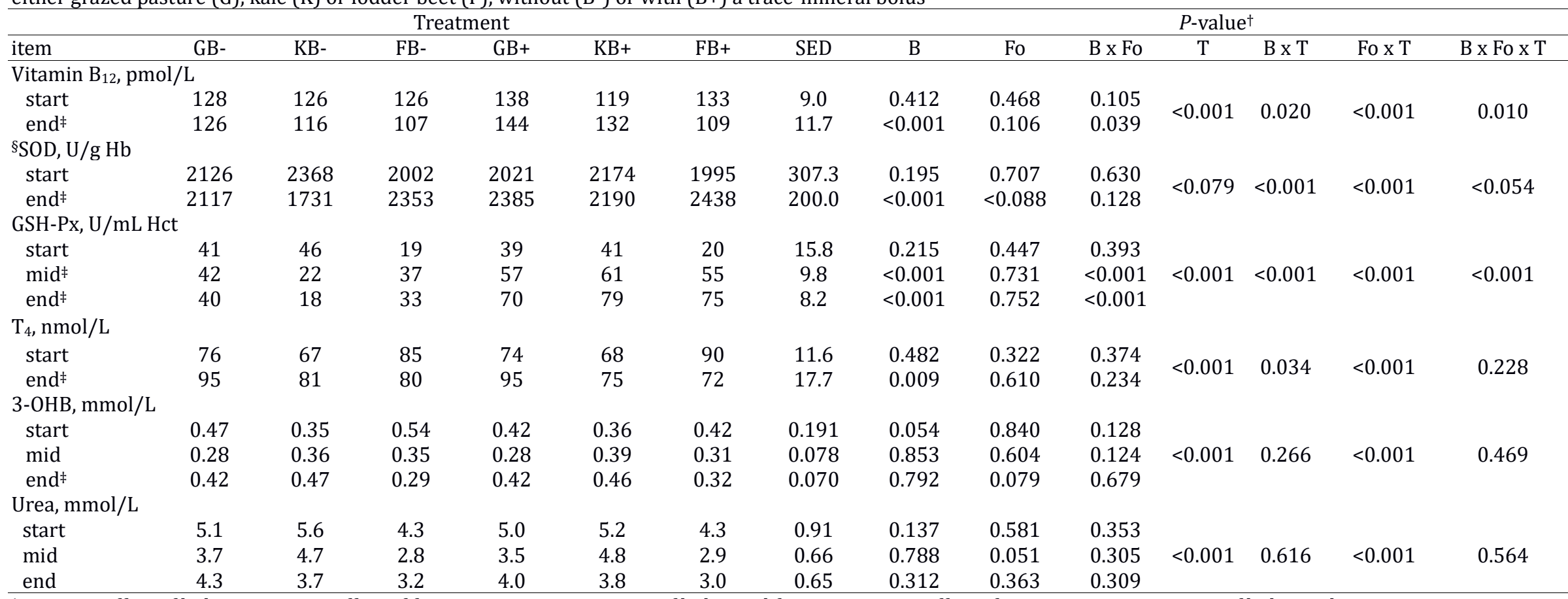

${ }_{\mathrm{t}} \mathrm{B}=$ main effect of bolus, Fo = main effect of forage, $\mathrm{B} \times$ Fo $=$ interaction of bolus and forage, $\mathrm{T}=$ main effect of time, $\mathrm{B} \times \mathrm{T}=$ interaction of bolus and time, Fo $\mathrm{T}=$ interaction of forage and time, $\mathrm{B} \times \mathrm{Fo} \times \mathrm{T}=$ interaction of bolus, forage and time

$\ddagger$ means adjusted for start value covariate

$\S \mathrm{SOD}=$ superoxide dismutase; GSH-Px = glutathione peroxidase; $\mathrm{T}_{4}=$ thyroxine; 3 -OHB = $\beta$-hydroxybutyrate 
Table 5

Haematology at the beginning, middle and end of a three month out-wintering period, in pregnant crossbred dairy heifers out-wintered on either grazed pasture (G), kale (K) or fodder beet (F), without (B-) or with (B+) a trace-mineral bolus

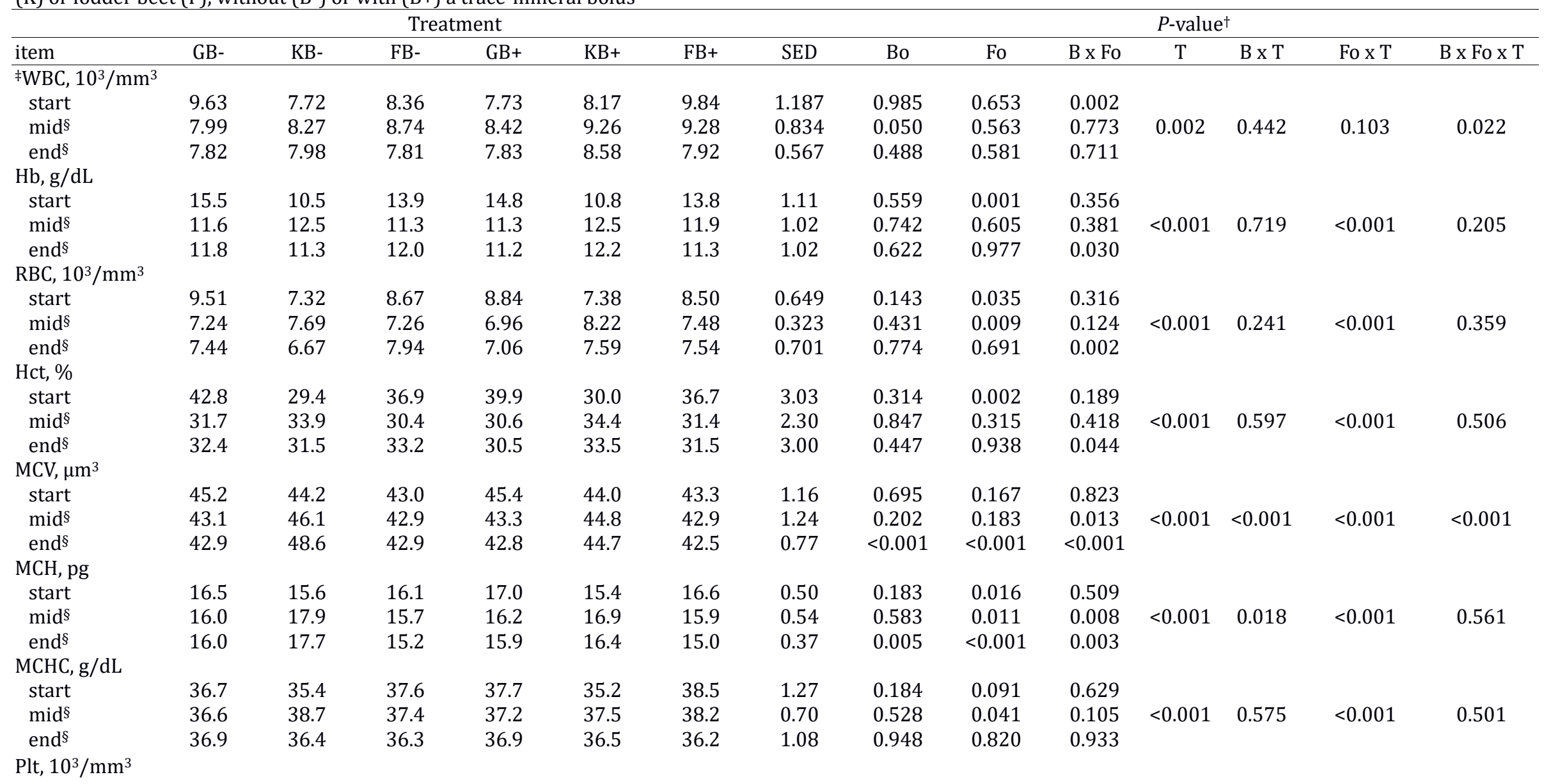




\begin{tabular}{|c|c|c|c|c|c|c|c|c|c|c|c|c|c|c|}
\hline start & 337 & 217 & 254 & 316 & 248 & 288 & 91.5 & 0.599 & 0.641 & 0.593 & & & & \\
\hline $\operatorname{mid}^{\S}$ & 310 & 298 & 320 & 368 & 323 & 257 & 79.0 & 0.900 & 0.789 & 0.185 & 0.091 & 0.968 & 0.061 & 0.389 \\
\hline end $\S$ & 330 & 239 & 366 & 349 & 258 & 348 & 89.4 & 0.854 & 0.508 & 0.796 & & & & \\
\hline
\end{tabular}

${ }^{\mathrm{H}} \mathrm{B}=$ main effect of bolus, Fo = main effect of forage, $\mathrm{B} \times$ Fo $=$ interaction of bolus and forage, $\mathrm{T}=$ main effect of time, $\mathrm{B} \times \mathrm{T}=$ interaction of bolus and time, Fo $\mathrm{x} T=$ interaction of forage and time, $\mathrm{B} \times$ Fo $\mathrm{x} T=$ interaction of bolus, forage and time

$\neq \mathrm{WBC}=$ white blood cell; $\mathrm{Hb}=$ haemoglobin; $\mathrm{RBC}=$ red blood cells; Hct = haematocrit; $\mathrm{MCV}=$ mean corpuscular volume; $\mathrm{MCH}=$ mean corpuscular haemoglobin; $\mathrm{MCHC}=$ mean corpuscular haemoglobin concentration; Plt = platelets.

§means adjusted for initial value covariate 
Table 6

Average daily gain (ADG), body weight (BW), body condition score (BCS) and coat length at the beginning, middle and end of a three month out-wintering period, in pregnant crossbred dairy heifers out-wintered on either grazed pasture $(G)$, kale $(K)$ or fodder beet (F), without (B-) or with (B+) a trace-mineral bolus

\begin{tabular}{|c|c|c|c|c|c|c|c|c|c|c|c|c|c|}
\hline \multicolumn{8}{|c|}{ Treatment } & \multicolumn{6}{|c|}{$P$-value ${ }^{\dagger}$} \\
\hline item & GB- & KB- & FB- & GB+ & $\mathrm{KB}+$ & $\mathrm{FB}+$ & SED & $\mathrm{B}$ & Fo & $\mathrm{B} \times \mathrm{Fo}$ & $\mathrm{T}$ & $\mathrm{B} \times \mathrm{T}$ & Fo $\times \mathrm{T}$ \\
\hline ADG,g/d & 205 & 393 & 136 & 145 & 438 & 152 & 198.0 & 0.988 & 0.452 & 0.169 & & & \\
\hline BW, kg & & & & & & & & & & & & & \\
\hline start & 428 & 399 & 385 & 430 & 400 & 383 & 16.8 & 0.816 & 0.086 & 0.291 & & & \\
\hline $\operatorname{mid}^{\ddagger}$ & 411 & 429 & 412 & 408 & 432 & 413 & 13.3 & 0.674 & 0.387 & 0.117 & $<0.001$ & 0.968 & $<0.001$ \\
\hline end $\neq$ & 423 & 435 & 413 & 418 & 439 & 414 & 15.3 & 0.968 & 0.415 & 0.135 & & & \\
\hline BCS, $1-5$ & & & & & & & & & & & & & \\
\hline start & 2.73 & 2.71 & 2.56 & 2.73 & 2.73 & 2.54 & 0.130 & 1.000 & 0.421 & 0.769 & & & \\
\hline mid & 2.60 & 2.58 & 2.61 & 2.63 & 2.55 & 2.60 & 0.057 & 0.752 & 0.709 & 0.330 & $<0.001$ & 0.146 & $<0.001$ \\
\hline end & 2.44 & 2.45 & 2.41 & 2.48 & 2.46 & 2.47 & 0.068 & 0.024 & 0.952 & 0.376 & & & \\
\hline Coat leng & & & & & & & & & & & & & \\
\hline $\begin{array}{l}\text { start } \\
\text { end }\end{array}$ & $\begin{array}{l}20.8 \\
26.2\end{array}$ & $\begin{array}{l}20.5 \\
24.9\end{array}$ & $\begin{array}{l}21.4 \\
24.3\end{array}$ & $\begin{array}{l}21.8 \\
26.2\end{array}$ & $\begin{array}{l}20.0 \\
24.6\end{array}$ & $\begin{array}{l}22.1 \\
26.1\end{array}$ & $\begin{array}{l}0.87 \\
1.41\end{array}$ & $\begin{array}{l}0.423 \\
0.282\end{array}$ & $\begin{array}{l}0.057 \\
0.617\end{array}$ & $\begin{array}{l}0.345 \\
0.121\end{array}$ & $<0.001$ & 0.715 & 0.125 \\
\hline
\end{tabular}

$+\mathrm{B}=$ main effect of bolus, $\mathrm{Fo}=$ main effect of forage, $\mathrm{B} \times \mathrm{Fo}=$ interaction of bolus and forage, $\mathrm{T}=$ main effect of time, $\mathrm{Bo} \times \mathrm{T}=$ interaction of bolus and time, $\mathrm{Fo} \times \mathrm{T}=$ interaction of forage and time. Interaction of B, Fo and T was not significant $(p>.05)$

$\ddagger$ means adjusted for initial value covariate 